\title{
Analisis dan Perancangan Sistem Pengumpulan Data Bencana Alam
}

\author{
Theresia Devi Indriasari $^{1}$, Kusworo Anindito ${ }^{2}$, Eddy Julianto ${ }^{3}$ \\ Program Studi Teknik Informatika, Universitas Atma Jaya Yogyakarta \\ Jl. Babarsari 43, Yogyakarta 55281, Indonesia \\ E-mail: ${ }^{1}$ dev@ staff.uajy.ac.id, ${ }^{2}$ kusworo@ ${ }^{2}$ taff.uajy.ac.id, ${ }^{3}$ eddiedb@ staff.uajy.ac.id
}

Masuk: 23 September 2014; Direvisi: 6 oktober 2014; Diterima: 5 November 2014

\begin{abstract}
Disaster management is the responsibility of the central and local governments. Fast and accurate data are needed during a disaster so that disaster necessary actions can be organized quickly, accurately, and thoroughly by government agencies. Information and communication technologies have a major role in helping the process of collecting data accurately and fast. This study developes a prototype system that can be used to perform natural disaster data collection through mobile devices. Furthermore, the data collected will be presented in a web form and displayed on a map, making it easier to monitor situations and disaster victims. This study utilizes the SMS-gateway technology and location-based services in its implementation.
\end{abstract}

Keywords: natural disasters, mobile, web, SMS-gateways, location-based services

\begin{abstract}
Abstrak. Tindakan penanganan bencana merupakan tanggung jawab dari pemerintah pusat dan pemerintah daerah. Data yang akurat dan cepat pada saat bencana dibutuhkan agar penanggulangan bencana dapat dilakukan dengan cepat, tepat, terkoordinasi dan menyeluruh dengan instansi-instansi pemerintah yang terkait. Teknologi informasi dan komunikasi mempunyai peranan besar dalam membantu proses pengumpulan data yang akurat dan cepat. Penelitian ini mengembangkan prototype sistem yang dapat digunakan untuk melakukan pengumpulan data bencana alam melalui piranti mobile. Selanjutnya data yang terkumpul akan disajikan dalam bentuk web dan tertampil pada peta, sehingga memudahkan instansi terkait dalam memantau kondisi bencana dan korban bencana. Penelitian ini memanfaatkan teknologi SMS-gateway dan layanan berbasis lokasi dalam implementasinya.
\end{abstract}

Kata kunci: bencana alam, mobile, web, SMS-gateway, layanan berbasis lokasi

\section{Pendahuluan}

Indonesia merupakan negara kepulauan yang secara geografis terletak pada pertemuan empat lempeng tektonik yaitu lempeng Indo Australia, Eurasia dan Pasifik. Pada bagian selatan dan timur Indonesia terdapat sabuk vulkanik yang berupa pegunungan vulkanik. Kondisi tersebut menyebabkan Indonesia sangat berpotensi terhadap kerawanan bencana seperti letusan gunung berapi, gempa bumi, tsunami, banjir dan tanah longsor. Bahkan dari data United States Geological Survey (USGS) menunjukkan bahwa Indonesia merupakan salah satu Negara yang memiliki tingkat kegempaan tertinggi di dunia (Sipahutar, 2013).

Menurut UU nomor 24 tahun 2007 bencana didefinisikan sebagai "peristiwa atau rangkaian peristiwa yang mengancam dan mengganggu kehidupan dan penghidupan masyarakat yang disebabkan, baik oleh faktor alam dan/atau faktor nonalam maupun faktor manusia sehingga mengakibatkan timbulnya korban jiwa manusia, kerusakan lingkungan, kerugian harta benda, dan dampak psikologis." Pada saat bencana terjadi, kegiatan tanggap darurat bencana merupakan hal yang penting untuk dilakukan. Kegiatan ini untuk menangani dampak buruk yang ditimbulkan, yang meliputi kegiatan penyelamatan dan evakuasi korban, harta benda, pemenuhan kebutuhan dasar, perlindungan, pengurusan pengungsi, penyelamatan, serta pemulihan prasarana dan sarana.

Penanganan bencana merupakan tanggung jawab dari pemerintah dan pemerintah daerah. Prinsip-prinsip dalam penanggulangan bencana antara lain adalah cepat dan tepat, prioritas, 
koordinasi dan keterpaduan, berdaya guna dan berhasil guna. Tujuan utama penanggulangan bencana adalah memberikan perlindungan kepada masyarakat dari ancaman bencana dan menjamin terselenggaranya penanggulangan bencana secara terencana, terpadu, terkoordinasi, dan menyeluruh (UU No. 24, 2007).

Pelaksana penanggulangan bencana menurut UU nomor 24 tahun 2007 adalah Badan Nasional Penanggulangan Bencana (BNPB). BNPB membutuhkan data yang akurat pada saat bencana terjadi agar bisa melakukan penanggulanan bencana yang cepat dan tepat serta terkoordinasi dan menyeluruh dengan instansi-instansi pemerintah yang terkait. Maka dibutuhkan suatu sistem yang dapat membantu proses pengumpulan data bencana dan korban bencana.

Penelitian ini bertujuan untuk membangun suatu prototype sistem yang dapat membantu dan mempercepat pengumpulan data bencana alam dan korban bencana. Penelitian ini terbagi dalam dua tahap besar, pertama analisis dan perancangan prototype sistem, kedua pembangunan prototype sistem. Dalam tulisan ini hanya dipaparkan bagian tahap pertama penelitian. Penelitian ini akan mengembangkan sistem dalam dua platform. Pertama, platform mobile yang digunakan oleh para petugas/relawan untuk mencatat data yang dibutuhkan di lokasi bencana. Kedua, platform web dimana data yang dikumpulkan oleh para relawan/petugas lapangan akan disimpan server dan ditampilkan pada peta untuk memudahkan petugas dalam melakukan koordinasi penanganan bencana.

\section{Tinjauan Pustaka}

Bencana adalah Peristiwa atau rangkaian peristiwa yang mengancam dan mengganggu kehidupan dan penghidupan masyarakat yang disebabkan, baik oleh faktor alam dan/atau faktor non alam maupun faktor manusia sehingga mengakibatkan timbulnya korban jiwa manusia, kerusakan lingkungan, kerugian harta benda, dan dampak psikologis. (Definisi bencana menurut UU No. 24 tahun 2007).

Berikut ini beberapa fase dalam siklus manajemen bencana (Wattegama, 2007): (1) Mitigasi (Mitigation): setiap kegiatan yang mengurangi baik kemungkinan bahaya yang terjadi atau bahaya yang berubah menjadi bencana. (2)Pengurangan risiko (Risk Reduction): langkahlangkah antisipatif dan tindakan yang berusaha untuk menghindari risiko di masa depan sebagai hasil bencana. (3)Pencegahan (Prevention): menghindari bencana. (4)Kesiapsiagaan (Preparedness): rencana atau persiapan yang dibuat untuk menyelamatkan nyawa atau harta, dan membantu respon dan penyelamatan operasi layanan. Fase ini meliputi pelaksanaan/operasi, peringatan dini sistem dan pembangunan kapasitas sehingga penduduk akan bereaksi dengan tepat ketika awal peringatan dikeluarkan. (5)Respon (Response): termasuk tindakan yang diambil untuk menyelamatkan nyawa dan mencegah kerusakan properti, dan melestarikan lingkungan selama keadaan darurat atau bencana. Fase respon adalah pelaksanaan rencana aksi.6) Pemulihan (Recovery): mencakup tindakan-tindakan yang membantu masyarakat untuk kembali ke keadaan normal setelah bencana.

Berikut akan dibahas bagaimana teknologi informasi dapat digunakan secara efektif untuk mengatasi masalah dalam periode pasca-bencana. (1) Sahana-Sistem Manajemen Bencana pada Tsunami 2004 dan Gempa Bumi Pakistan 2005. Sahana merupakan sistem yang sifatnya free dan open source yang dikembangkan oleh Lank Software Foundation. Sistem ini berbasis web yang menyediakan solusi untuk masalah yang timbul pada kondisi setelah bencana. Salah satu contoh solusi yang diberikan adalah merekam lokasi kamp sementara dan posko bencana. Hal ini sangat penting untuk menyalurkan bantuan secara efektif dan memastikan bahwa tidak ada daerahdaerah yang sengaja diabaikan. Sebuah aplikasi sub-sistem Sahana melacak lokasi dari semua kamp-kamp di wilayah tersebut dan merekam fasilitas yang dimiliki dan jumlah orang di dalam kamp tersebut. (Careem dkk., 2006). (2) Penggunaan Internet pasca gempa bumi 1999 di Turki.Pada 17 Agustus 1999 gempa bumi melanda Turki yang mengakibatkan 15.000 orang meninggal dunia, lebih dari 120.000 rumah rusak parah. Infrastruktur telekomunikasi rusak parah sehingga layanan telepon tidak dapat digunakan, sedangkan telepon seluler dapat beroperasi dengan bandwidth yang terbatas. Pada situasi ini Internet merupakan satu-satunya media yang dapat menghubungkan daerah bencana dan dunia luar. Beberapa aplikasi Internet digunakan pada 
pasca bencana terutama untuk mengatasi masalah koordinasi penyebaran bantuan dan mencari informasi orang yang hilang. (Zincir-Heywood \& Heywood, 2000).

Penelitian ini memanfaatkan teknologi SMS gateway dan layanan berbasis lokasi untuk memberikan layanan kepada pengguna. Layanan berbasis lokasi merupakan layanan yang menggunakan lokasi sebagai target nilai dan layanannya untuk menyeleksi informasi tentang area tertentu (Küpper, 2005). Layanan ini mempunyai kemampuan untuk menggunakan lokasi dari piranti mobile (Virrantaus et al, 2001). Lima komponen utama dalam layanan berbasis lokasi yaitu: (1) piranti mobile, (2) jaringan komunikasi, (3) positioning component, (4) penyedia layanan dan aplikasi, (5) penyedia data dan konten (Steiniger et al, 2006).

Layanan berbasis lokasi membutuhkan GPS (Global Positioning System) yang memungkinkan penerima GPS untuk mendapatkan lokasinya di permukaan bumi. Orbit-orbit satelit GPS diatur sedemikian rupa, sehingga suatu tempat di bumi dapat dijangkau minimal oleh empat satelit (Gintoro, et.al 2010). GPS digunakan dalam layanan berbasis lokasi karena GPS dapat mendeteksi lokasi dengan tepat, tingkat akurasinya mencapai 10meter. Aplikasi gawat darurat, pertolongan, dan navigasi yang memanfaatkan layanan berbasis lokasi memiliki tingkat penerimaan pengguna lebih tinggi dibandingkan jenis aplikasi lain (Park, 2009).

Dalam penelitian ini koordinat penerima GPS ditampilkan dalam sebuah peta lokasi. Peta adalah kumpulan titik (points), garis (lines), dan bidang/area/poligon (areas/polygon) yang dinyatakan letak lokasi dalam ruang yang mengacu pada suatu sistem koordinat dan atribut non spasial (Kiser, et.al 2010). Peta lokasi yang digunakan dalam penelitian ini adalah Google Maps. Google Maps menampilkan unsur teks, gambar, link, dan mengarah pada aplikasi lain (Chan, et.al 2005). Melalui penggunaan Google Map API aplikasi yang dibuat mampu menampilkan gambaran peta berdasarkan posisi koordinat tertentu yang ditampilkan dari Google Maps (Jarayam, et.al 2008). Penggunaan Google Maps yang diimplementasikan pada Location-Based Service juga mempermudah untuk mencari lokasi yang menjadi tujuan (Santi, 2010).

\section{Metodologi Penelitian}

Metodologi yang digunakan dalam pembangunan sistem pengumpulan data bencana alam terbagi dalam dua tahap besar. Tahap Pertama meliputi kegiatan studi literatur, studi lapangan, analisis kebutuhan sistem, perancangan dan pembuatan prototype. (1) Studi literatur dilakukan untuk mendapatkan informasi mengenai cara penanganan bencana alam. (2) Studi lapangan dilakukan di lokasi bencana alam dan Badan Penanggulangan Bencana Daerah. (3) Analisis kebutuhan sistem dilakukan untuk mengetahui kebutuhan sistem baik fungsional maupun non fungsional. Tahapan ini akan menghasilkan spesifikasi sistem dan kebutuhan fungsionalitas yang harus tersedia dalam sistem serta arsitektur informasi yang tepat untuk menyajikan informasi mengenai data bencana. (4) Perancangan dan pembuatan prototype sistem dilakukan untuk menghasilkan rancangan sistem berdasarkan hasil analisis pada tahap sebelumnya. Hasil rancangan berupa arsitektur sistem, basis data, dan antarmuka sistem. Antar muka sistem disini adalah antar muka bersifat low fidelity prototype (sketsa). Sedangkan untuk tahapan pembuatan prototype akan menghasilkan antar muka sistem yang bersifat high fidelity prototype (mendekati produk jadi)

Tahap Kedua meliputi kegiatan pengembangan prototype dan pengujian prototype (1) Pengembangan prototype dilakukan untuk menghasilkan prototype sistem secara keseluruhan. (2) Pengujian dilakukan untuk mengetahui kelebihan dan kekurangan prototype baik dari aspek fungsionalitas maupun user acceptance.

\section{Pembahasan}

Penelitian ini baru mencapai tahap pertama yaitu menghasilkan antar muka sistem yang bersifat high fidelity prototype. Berikut akan dibahas hasil penelitian pada tahap pertama. Gambar 1 memperlihatkan ilustrasi metodologi penelitian pada tahap pertama seperti dijelaskan pada bab 3. 


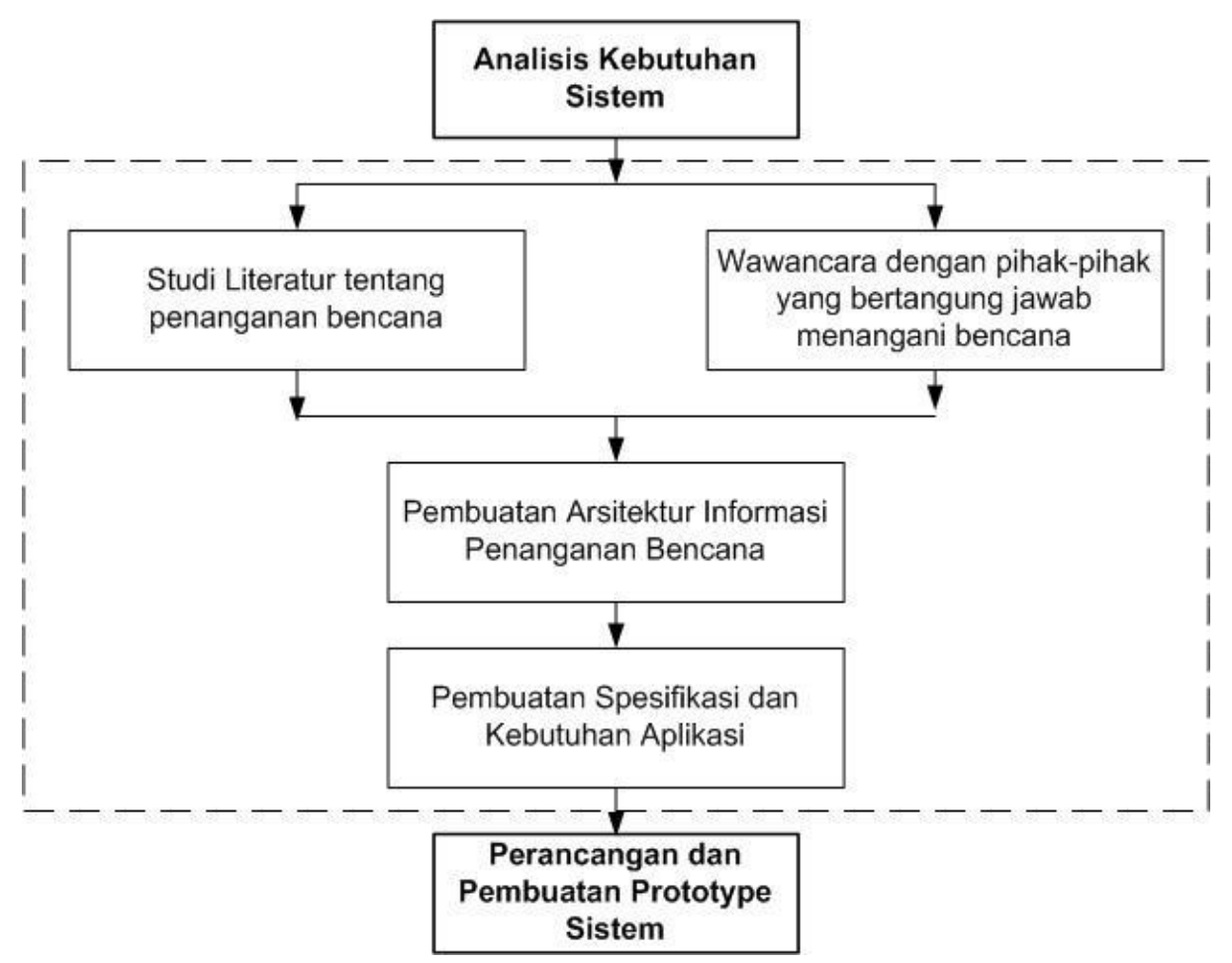

Gambar 1. Metodologi Penelitian Tahap Pertama

\subsection{Analisis Kebutuhan Sistem}

Studi literatur dilakukan dengan mencari informasi-informasi melalui media Internet yang berkaitan dengan penanganan bencana alam. Wawancana dilakukan di salah satu lokasi bencana alam di wilayah lereng Gunung Merapi dan pihak Badan Penanggulangan Bencana Daerah. Dalam penelitian ini, lokasi bencana alam yang dipilih adalah di wilayah lereng merapi dengan pertimbangan bahwa di tahun 2010 terjadi bencana alam erupsi merapi dengan korban cukup banyak yang membutuhkan penanganan bencana secara terencana, terpadu, terkoordinasi, dan menyeluruh. Badan Penanggulanan Bencana Daerah (BPBD) yang dipilih adalah BPBD dalam lingkup propinsi yaitu Pemerintah Daerah DIY.

Pada saat bencana alam terjadi, salah satu proses penanggulangan bencana yang penting adalah tanggap darurat. Dalam tanggap darurat hal pertama yang harus dilakukan adalah pengkajian secara tepat terhadap lokasi, kerusakan dan sumber daya (Gubernur Daerah Istimewa Yogyakarta, 2011). Kepala BNPB membentuk Tim Reaksi Cepat (TRC) terdiri dari instansi/lembaga teknis/non teknis terkait yang bertugas melaksanakan kegiatan kaji cepat bencana dan dampak bencana pada saat tanggap darurat meliputi penilaian kebutuhan (Needs Assessment), penilaian kerusakan dan kerugian (Damage and Loses Assessment) serta memberikan dukungan pendampingan (membantu SATKORLAK PB/BPBD Provinsi/ SATLAK PB/BPBD Kabupaten/Kota) dalam penanganan darurat bencana (Kepala Badan Nasional Penanggulangan Bencana, 2008). Fungsi TRC BNPB antara lain: (1) Melaksanakan pengkajian awal segera setelah terjadi bencana pada saat tanggap darurat. (2) Membantu SATKORLAK PB/BPBD Provinsi/SATLAK PB/BPBD Kabupaten/Kota untuk mengaktivasi Posko SATKORLAK PB/BPBD Provinsi/SATLAK PB/BPBD Kabupaten/Kota, memperlancar koordinasi dengan seluruh sektor yang terlibat dalam penanganan bencana, menyampaikan saran yang tepat dalam untuk upaya penanganan bencana. (3) Melaporkan hasil pelaksanaan tugas secara periodik kepada Kepala BNPB dengan tembusan atasan langsung anggota Tim dari sektor terkait dan SATKORLAK PB/BPBD Provinsi/SATLAK PB/BPBD Kabupaten/Kota dalam bentuk laporan awal setelah tiba di lokasi bencana, laporan berkala/perkembangan (harian dan insidentil/ khusus), dan laporan lengkap/akhir penugasan. Gambar 2 memperlihatkan salah satu contoh format laporan awal TRC. 


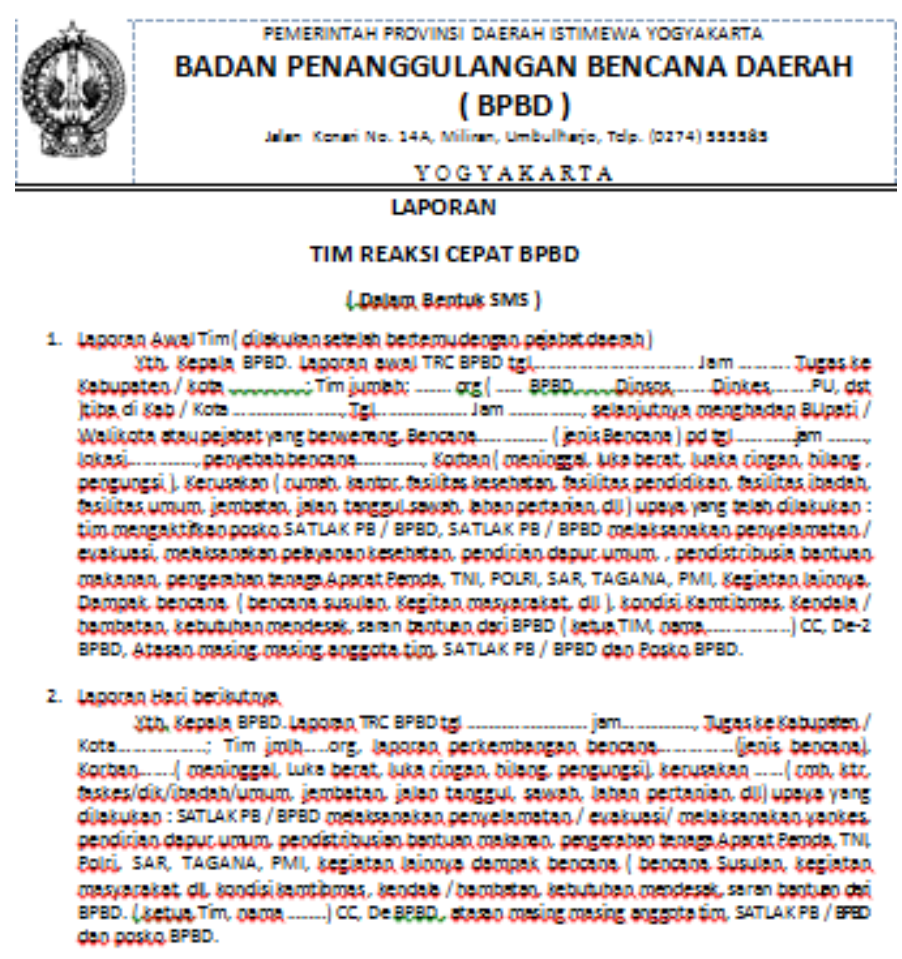

\section{Gambar 2. Format Laporan TRC BPBD Dalam Bentuk SMS}

Sistem yang akan dikembangkan terdiri dari dua platform. Pertama, platform mobile yang digunakan oleh para petugas TRC/relawan untuk mencatat data yang dibutuhkan di lokasi bencana. Kedua, platform web dimana data yang dikumpulkan oleh para relawan/petugas lapangan akan disimpan server dan ditampilkan pada peta untuk memudahkan petugas/relawan/aparat dalam melakukan koordinasi penanganan bencana, bahkan situs web dapat diakses oleh publik yang menginginkan melihat kondisi terkini terkait dengan bencana alam. Secara lengkap arsitektur informasi sistem dapat dilihat pada Gambar 3.

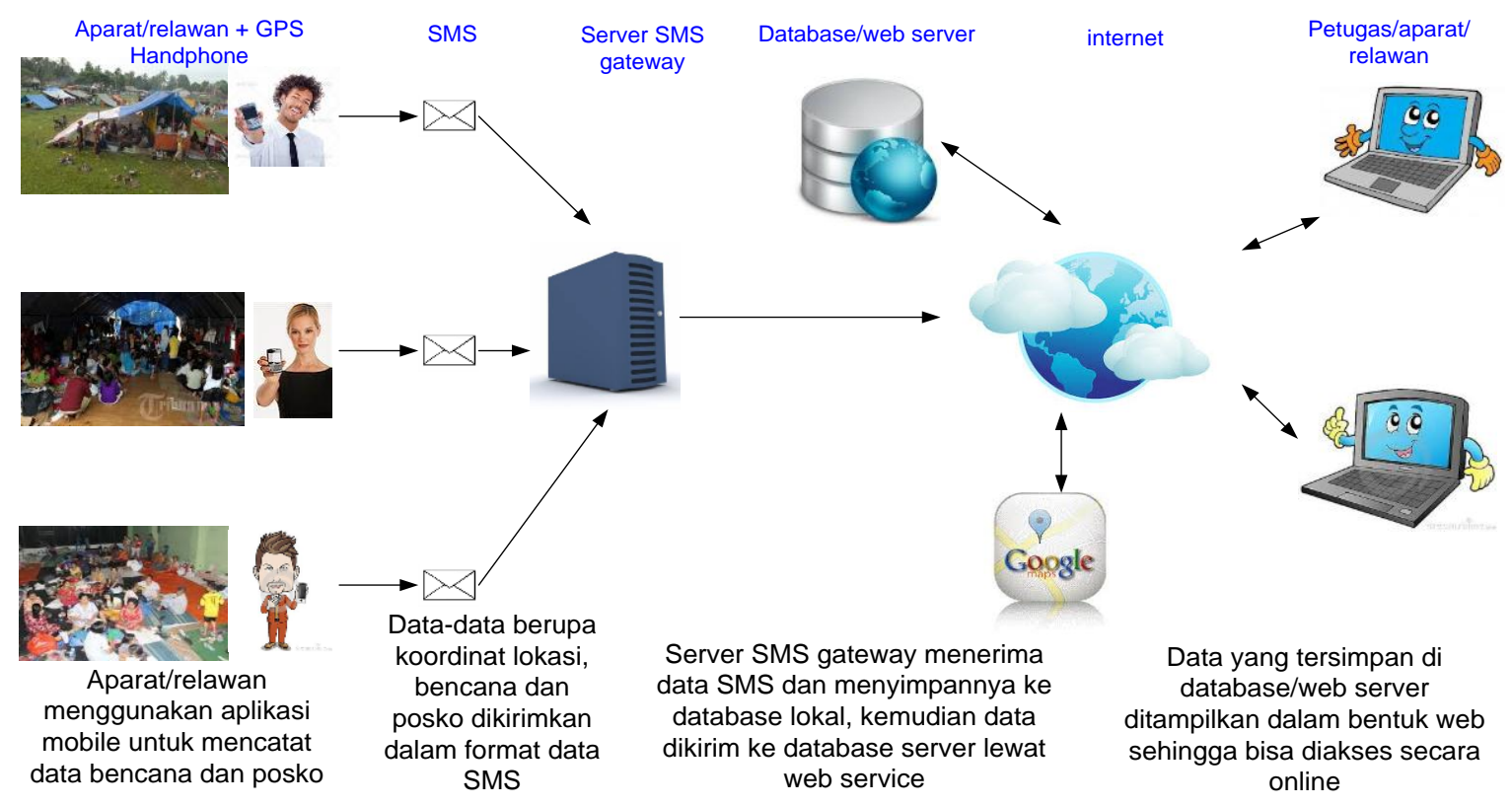

Gambar 3. Arsitektur Informasi Sistem 
Pada saat bencana alam terjadi tim TRC menggunakan mobile phone yang memiliki fasilitas GPS dan telah terinstall aplikasi yang telah dikembangkan untuk mengumpulkan data. Data yang dikumpulkan oleh tim TRC bisa berupa laporan awal bencana, laporan perkembangan bencana, laporan awal posko atau laporan perkembangan posko. GPS dibutuhkan untuk mendapatkan posisi longitude dan latitude bencana atau posko. Data kemudian dikirimkan ke server SMS-gateway dalam bentuk format data SMS menggunakan layanan SMS provider telekomunikasi seluler. Pada saat studi lapangan didapatkan informasi bahwa jaringan komunikasi yang tersedia di sekitar area lereng Merapi dan tempat pengungsian cukup bagus, baik untuk layanan suara (telepon) maupun pesan (SMS).

Server SMS-gateway menerima data dari berbagai relawan dan menyimpannya ke dalam database lokal. Selanjutnya data yang disimpan di database lokal tersebut secara periodik dikirimkan ke databaselweb server melalui web service. Data bencana yang tersimpan di database/web server ditampilkan dalam situs web yang bisa diakses secara online oleh petugas terkait. Web server menggunakan layanan Google Map API untuk menyajikan data bencana dan posko dalam bentuk peta.

Kebutuhan fungsionalitas sistem secara detil, baik dari sisi platform mobile maupun platform web digambarkan dalam dalam bentuk use case diagram seperti terlihat pada Gambar 4 dan Gambar 5. Gambar 4 merupakan use case diagram untuk aplikasi mobile yang mempunyai fungsionalitas umum untuk mengumpulkan laporan bencana. Gambar 5 merupakan use case diagram untuk aplikasi web yang mempunyai fungsionalitas umum untuk menerima informasi berupa laporan bencana dan menampilkannya dalam bentuk laporan dan peta.

Use case diagram untuk platform mobile (lihat Gambar 4) menunjukkan aktor relawan/tim TRC dapat melakukan login, membuat laporan bencana dan membuat laporan posko. Dalam menentukan posisi bencana atau posko yang akurat dibutuhkan aktor location service. Hasilnya didapatkan posisi longitude dan latitude yang selanjutnya semua data dari proses login, membuat laporan bencana, posko dan posisi dikirimkan dengan bantuan aktor SMS gateway.

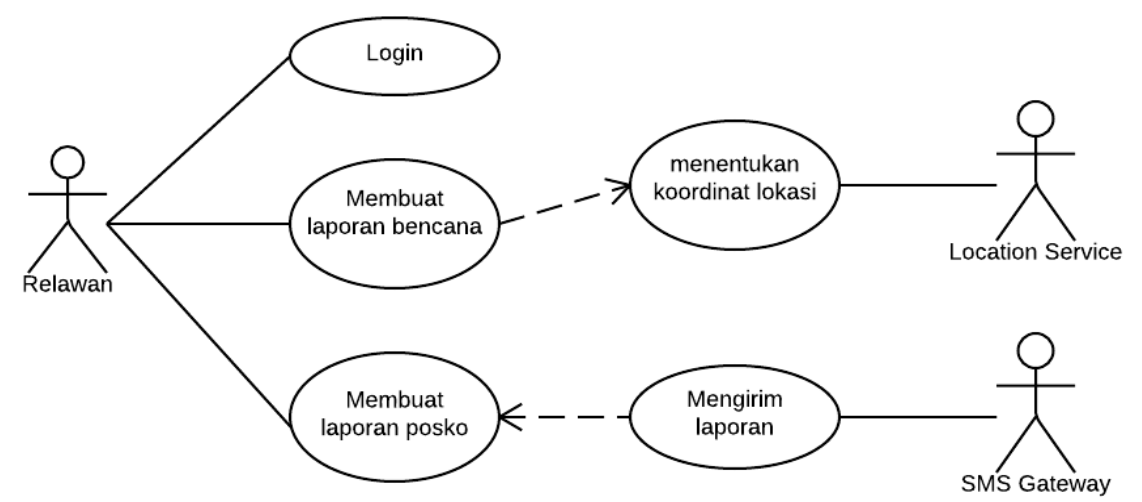

Gambar 4. Use case Aplikasi Mobile untuk Membuat Laporan Bencana

Use case diagram untuk platform web (lihat Gambar 5) menunjukkan aktor petugas dapat melakukan login dan menerima laporan yang dikirimkan oleh server SMS-gateway. Kemudian data yang diterima dan tersimpan di database server dapat ditampilkan dalam bentuk peta menggunakan bantuan dari Google Map API. Petugas juga dapat mengenerate laporan dalam bentuk format dokumen sesuai kebutuhan. Jika database/web server mempunyai masalah dalam menerima data dari server SMS-gateway, maka petugas dapat melakukan pencatatan data bencana, data posko, laporan bencana maupun laporan posko secara langsung ke dalam database server. Petugas juga mempunyai kewenangan untuk mengelola data petugas TRC yang terjun ke lokasi bencana dan mengirimkan beberapa data broadcast ke petugas TRC di lapangan. 


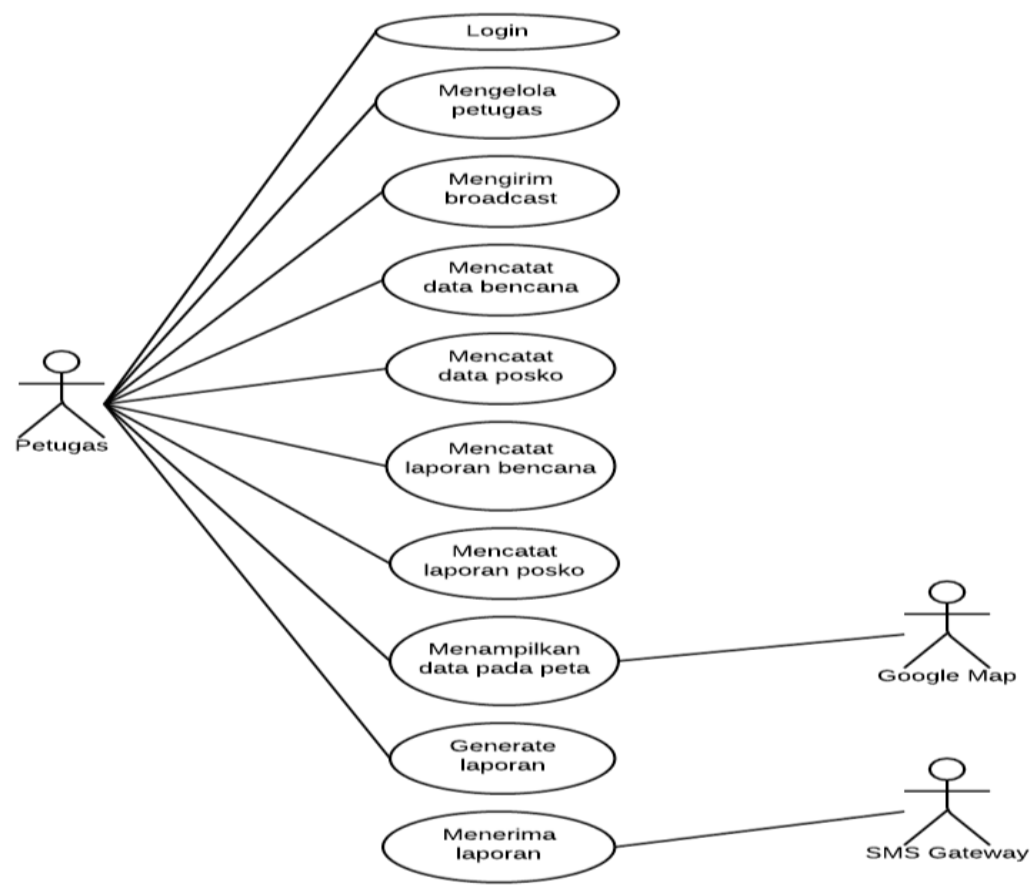

Gambar 5. Use case Aplikasi Web untuk Pemetaan Bencana

\subsection{Perancangan dan Pembuatan Prototype Sistem}

Berikut akan dipaparkan hasil perancangan sistem dalam bentuk entity relationship diagram (ERD) dan high fidelity prototype. Gambar 6 menunjukkan ERD (Entity Relationship Diagram) yang menggambarkan data model. ERD dibutuhkan untuk menggambarkan data atau informasi yang dibutuhkan untuk diimplementasikan dalam database sistem. Gambar 6 menunjukkan enam entities dan relasi antar entities tersebut. Enam entities tersebut antara lain untuk menyimpan data berkaitan dengan pengguna, role pengguna, bencana, laporan bencana, posko dan laporan posko.

Hasil perancangan dalam bentuk high fidelity prototype diperlihatkan dalam Gambar 7 sampai dengan Gambar 16. Prototype yang akan dikembangkan terbagi dalam dua bagian. Pertama, platform mobile dengan sistem operasi Android minimal 2.3. Kedua, platform web, dimana data dari server SMS-gateway akan dikirimkan ke database/web server untuk kemudian ditampilkan dalam bentuk laporan dan peta. Prototype berplatform web ini bisa diakses oleh petugas BPBD untuk digunakan dalam koordinasi penanggulangan bencana.

Pada dasarnya untuk prototype berbasis mobile, pengguna dapat memasukkan data berkaitan dengan bencana, baik dalam bentuk laporan awal maupun laporan perkembangan. Data yang dimasukkan sesuai dengan format laporan awal maupun perkembangan dari BPBD DIY, meliputi: jenis bencana, lokasi bencana, penyebab bencana, jumlah korban, jumlah pengungsi, jumlah kerusakan, dampak bencana, upaya penanganan apa saja yang telah dilakukan.

Pengguna juga dapat memasukkan data berkaitan dengan pendataan posko, seperti: nama posko, lokasi posko, kapasitas posko, jumlah fasilitas yang ada di posko (fasilitas dapur, kesehatan, MCK), jumlah pengungsi (pria, wanita, balita). 


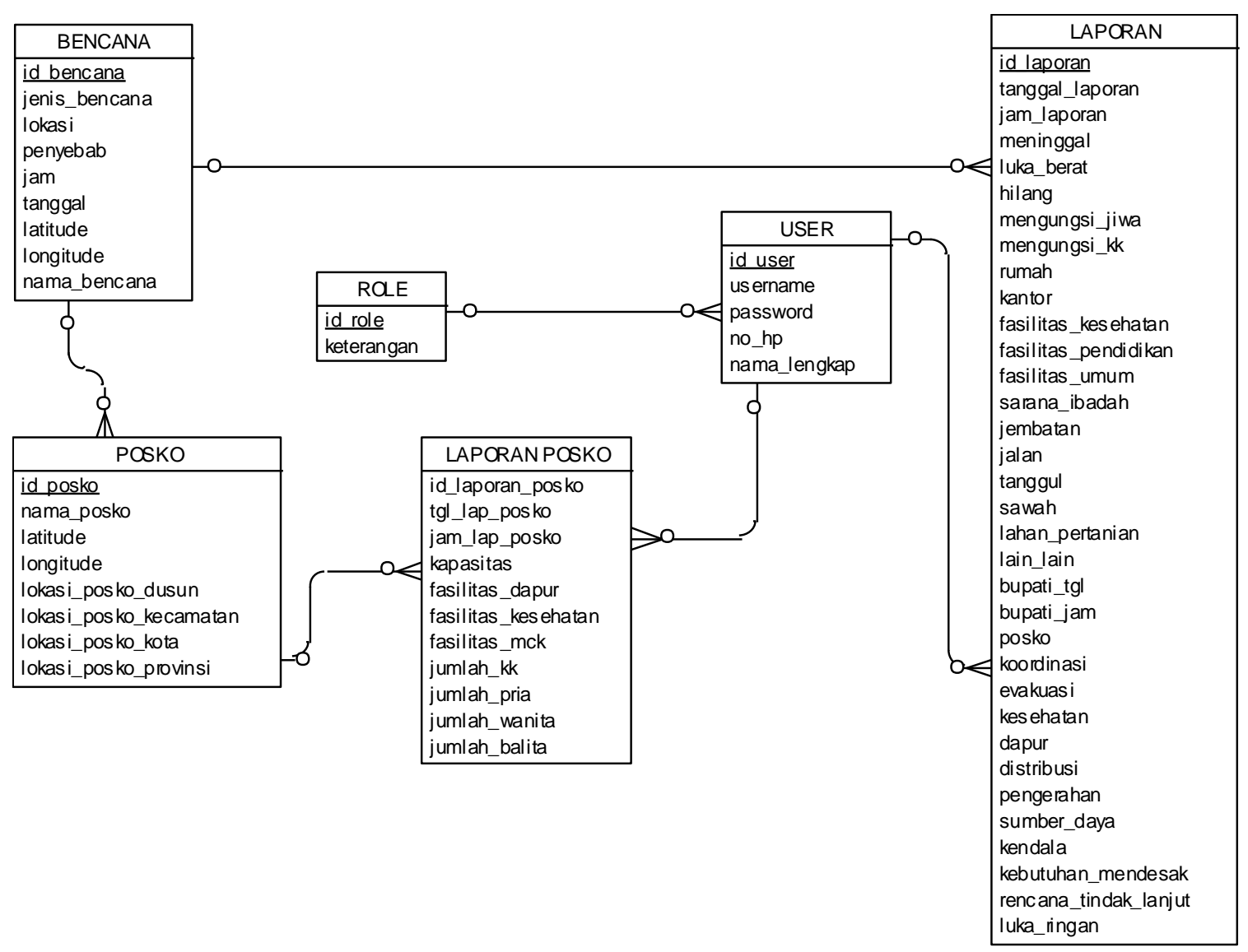

Gambar 6. ERD

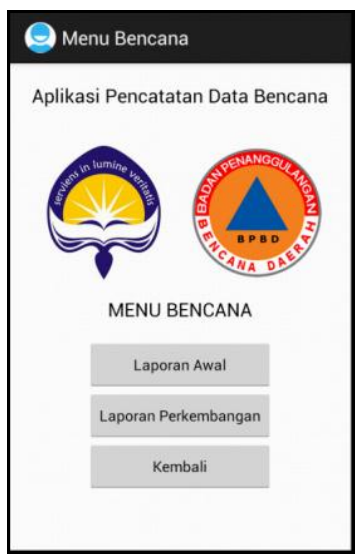

Gambar 7. Menu Bencana

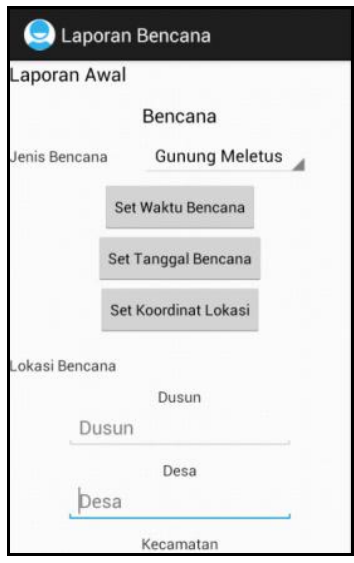

Gambar 8. Laporan Awal Bencana 1

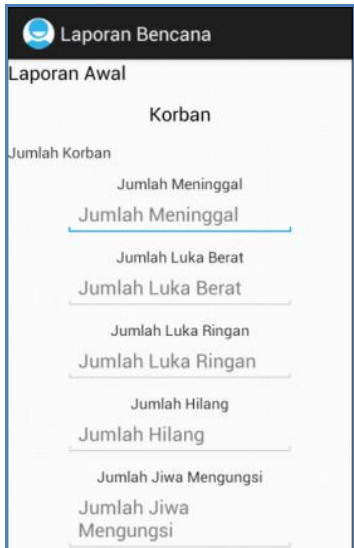

Gambar 9. Laporan Awal Bencana 2

\section{- Laporan Bencana}

Laporan Perkembangan

Korban

Masukan ID Bencana Yang Diterima

Jumlah Korban

$$
\text { Jumlah Meninggal }
$$

Jumlah Meninggal

Jumlah Luka Berat

Jumlah Luka Berat

Jumlah Luka Ringan

Jumlah Luka Ringan

Gambar 10. Laporan Perkembangan Bencana 


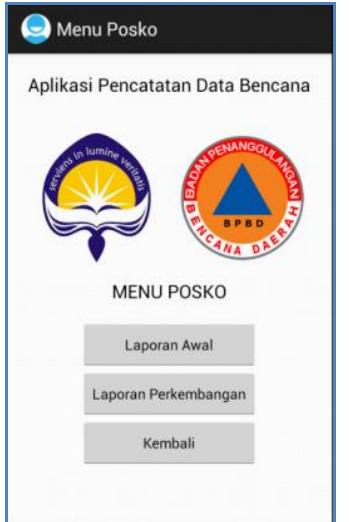

Gambar 11. Menu Posko

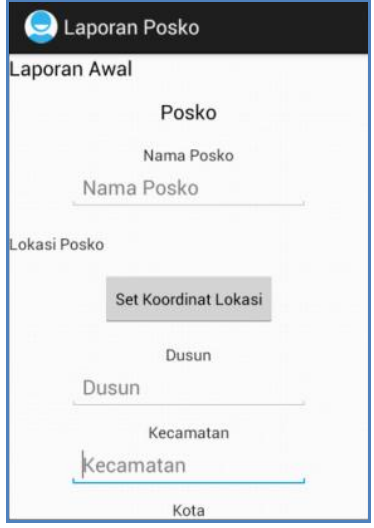

Gambar 12. Laporan Awal Posko 1

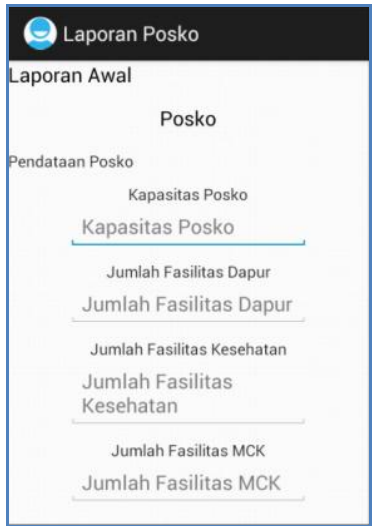

Gambar 13. Laporan Awal Posko 2

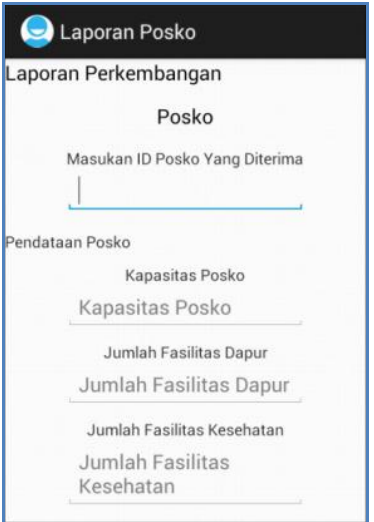

Gambar 14. Laporan Perkembangan Posko

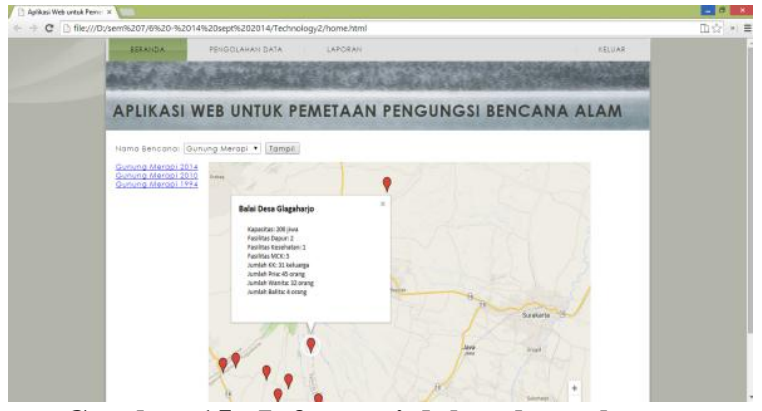

Gambar 15. Informasi dalam bentuk peta

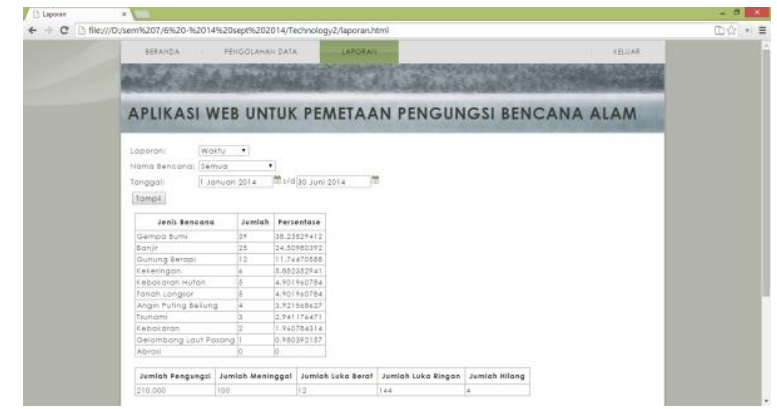

Gambar 16. Informasi dalam bentuk tabel

Pada prototype berbasis web (lihat Gambar 15 dan Gambar 16) akan menampilkan informasi bencana dalam bentuk laporan, dan akan ditampilkan data yang paling terkini dalam bentuk tabel. Laporan dapat di-import dalam bentuk format dokumen pdf. Selain itu, informasi bencana juga ditampilkan dalam bentuk peta untuk memperlihatkan lokasi bencana dan juga posko-posko yang didirikan dalam bentuk peta. Dalam peta juga memperlihatkan secara umum data pada masing-masing posko seperti yang telah dimasukkan oleh para petugas TRC/relawan di lokasi bencana. Contoh untuk Bencana Merapi, akan tertampil beberapa posko pengungsian dalam bentuk pin point. Jika salah satu pin point dipilih, missal posko Balai Desa Glagaharjo, maka akan tertampil informasi jumlah pengungsi, jumlah fasilitas dapur, fasilitas MCK, fasilitas kesehatan, jumlah kepala keluarga yang mengungsi, pria, wanita, dan balita yang mengungsi.

\section{Kesimpulan}

Berdasarkan pembahasan sebelumnya dapat diambil kesimpulan bahwa perangkat lunak Sistem Pengumpulan Data Bencana Alam telah menghasilkan high fidelity prototype. Penelitian ini melalui proses analisis dan perancangan perangkat lunak berdasarkan data dan informasi valid dari studi literatur dan studi lapangan yang terkait dengan pihak-pihak yang berhubungan dengan bencana.

\section{Referensi}

Careem, M.; De Silva, C.; De Silva, R.; Raschid, L.; Weerawarana, S.; Lanka Software Found., Colombo, 2006, Sahana: Overview of a Disaster Management System, Information and Automation, ICIA 2006, International Conference 15-17 Des 2006, pp. 361-366

Chan, Jian L., Gschwender, A., Workman, R., 2005, Campus Google Map Applications, Southern Connecticut State University.

Gintoro, Suharto, I. W., Rachman, F., Hali, Daniel, 2010, Analisis dan Perancangan Sistem Pencarian Taksi Terdekat dengan Pelanggan Menggunakan Layanan Berbasis Lokasi, 
Seminar Nasional Aplikasi Teknologi Informasi 2010 (SNATI 2010) ISSN: 1907-5022, Yogyakarta.

Gubernur Daerah Istimewa Yogyakarta. 2011. Peraturan Gubernur Daerah Istimewa Yogyakarta Nomor 49 Tahun 2011 Tentang Standar Operasional Prosedur Penanggulangan Bencana. Salinan diakses online dari http://bpbd.jogjaprov.go.id/wpcontent/uploads/2013/12/Salinan-Pergub-DIY-49-tahun-2011-ttg-SOP-PenanggulanganBencana.pdf, tanggal 10 Februari 2014.

Jayaram, Preethi, Nguyen, Trahan, S., M., Allred, I., 2008, Integrating Geocode Data from the Google Map API and SAS/Graph.

Kepala Badan Nasional Penanggulangan Bencana. 2008. Peraturan Kepala Badan Nasional Penanggulanan Bencana Nomor 9 Tahun 2008 Tentang Prosedur Tetap Reaksi Cepat Badan Nasional Penanggulanan Bencana. Salinan diakses online dari http://www.gitews.org/tsunami-

kit/en/E6/further_resources/national_level/peraturan_kepala_BNPB/Perka\%20BNPB\%2 09-2008_Protap\%20Tim\%20Reaksi\%20Cepat\%20BNPB.pdf, tanggal 1 Februari 2014.

Kiser, L. C., Kelly, J. Michael, 2010, GPS- vs. DEMDerived Elevation Estimates from a Hardwood Dominated Forest Watershed, Journal of Geographic Information System

Kupper, Axel, 2005, Location-Based Services: Fundamentals and Operation, John Wiley \& Sons. Meneses, F., Moreira, Adriano, 2003, Using GSM CellID Positioning for Place Discovering, Dept of Information Systems University of Minho Guimaraes, Portugal.

Park, Dongjoo, 2009, User Acceptance of Location-based Services, International Journal of Social Sciences, Vol. 4, no 2, hal 152-157.

UU nomor 24. 2007. UU nomor 24 tahun 2007 tentang penanggulangan bencana, Salinan diakses online dari http://bnpb.go.id/uploads/migration/pubs/1.pdf, tanggal 10 Februari 2014.

Santi, Yani, Ahmad., 2010, Kebutuhan Basis Data untuk aplikasi sistem informasi Geografi dalam Era Otonomi Daerah. Universitas Gajah Mada, Yogyakarta.

Sipahutar, A.M.J. 2013. Tanpa Mitigasi Bencana Indonesia 2014 Masih Menangis, diakses dari http://www.bmkg.go.id/bmkg_pusat/Lain_Lain/Artikel/Tanpa_Mitigasi_Bencana_Indon esia_2014_Masih_Menangis.bmkg. tanggal 1 Februari 2014.

Steiniger, Stefan, Moritz Neun dan Alistair Edwardes, 2006, Foundations of Location Based Services, Lecture Notes on LBS, V. 1.0

Virrantaus, K., Markkula, J., Garmash, A., Terziyan, Y.V., 2001, Developing GIS-Supported Location-Based Services, In: Proc. of WGIS'2001 - First International Workshop on Web Geographical Information Systems, Kyoto, Japan, 423-432.

Wattegama, C., 2007, ICT for Disaster Management, United Nations Development Programme Asia-Pacific Development Information Programme (UNDP-APDIP) and Asian and Pacific Training Centre for Information and Communication Technology for Development (APCICT) - 2007

Zincir-H., A.Nur dan Heywood, M.I., 2000, In the Wake of the Turkish Earthquake: Turkish Internet, Proceedings of the Internet Society's iNet 2000 conference. 